\title{
Pasi Enges
}

\section{Saamelainen kertomusperinne, tekijyys ja tekijänoikeudet}

\section{Folklore kirjoittamattomana kirjallisuutena}

Folkloristiikassa on käytetty kirjoittamaton kirjallisuus -termiä alan keskeiskäsitteen folkloren sijasta silloin, kun on haluttu painottaa suullisesti välittyvän kansanrunouden ja kertomusperinteen esteettistä ja sanataiteellista luonnetta. Sitä ovat käyttäneet tutkijat, jotka pitävät folklorea, huolimatta sen tyypillisesti kollektiivisesta ja anonyymista välittymisestä, pohjimmiltaan yksilöllisen luomistyön tuloksena ja siksi tietyin edellytyksin kirjoitettuun kirjallisuuteen rinnastettavana. (Kuusi 1963; Lehtipuro 1980, 8.) Käsitteen kansainvälisiä vastineita ovat brittiläisen tutkimuksen piirissä syntyneet ja tieteenalalla laajalti vakiintuneet oral literature ja verbal art (Finnegan 1992, 9-11).

On tavallista, että kirjakieleltään ja kirjallisuushistorialtaan nuorissa kulttuureissa folklore saa korostuneen aseman kirjoittamattomana kirjallisuutena tai ainakin kirjoitetun kirjallisuuden esiasteena ja perustana. Tämä pätee myös saamelaiskirjallisuuteen. Vuokko Hirvonen on esittänyt saamelaiskirjallisuuden kolmijaon, jossa ensimmäisen ryhmän muodostaa juuri kirjoittamaton kirjallisuus, kaiken suullisesti välittyvän joikuja kertomusperinteen kokonaisuus. Toista, historiallisesti katsottuna varsin suurta ryhmää Hirvonen nimittää siirtymävaiheen kirjallisuudeksi. Se on kirjallista, mutta tyylinsä ja sisältönsä puolesta lähellä suullista kirjallisuutta ja pikemmin dokumentaarista kuin taiteellista. Siirtymävaiheen kirjallisuus perustuu tavallisesti kirjoittajan omiin kokemuksiin ja on usein luonteeltaan mytologisen, historiallisen ja elämäkerrallisen aineksen yhdistelmä. Sen ensisijaisena tarkoituksena on kulttuurisen tiedon välittäminen tuleville sukupolville tai saamelaisen elämäntavan tekeminen tunnetuksi ulkopuolisille. Kolmas ryhmä on varsinainen kaunokirjallisuus, joka sekin voi hyödyntää perinteisiä aineksia, mutta vapaammin, kirjailijan omien taiteellisten päämäärien mukaisesti. (Hirvonen 1995, 21-22.) Saamelaiskirjallisuudesta puhuttaessa folkloreen on viitattu niin kaunokirjallisten tekstien sisältövarantona, inspiraation lähteenä, ilmaisukeinojen mallina kuin taiteen keinoin rakentuvan saamelaisidentiteetin tukijalkana (esim. Hirvonen 1995, 9-18, 39-40, 57-60; Hirvonen 1999, 91-94; Lehtola 1997, 96; SeurujärviKari 2011, 305).

Vuonna 1963 ilmestyneessä Suomen kirjallisuus I. Kirjoittamaton kirjallisuus -teoksessa Matti Kuusi korosti kirjallisuudentutkimuksen ja folkloristiikan lähtökohdissa vallitsevaa perustavanlaatuista eroa. Kun kirjallisuustieteilijällä "on alun pitäen käsissään tietyn kirjailijan tiettyä ajanympäristöä kuvastava tietynsisältöinen luomus", on folkloristilla edessään "tuhatlukuisten vaihtoehtojen vilinä" ja monitulkintainen tutkimus- 
aineisto hänen pyrkiessään "kohti tuntematonta runoa, tuntematonta runoniekkaa ja tämän tuntematonta miljöötä". (Kuusi 1963, 20-21.) Kuusen näkemys edusti omaa aikaansa ja folkloristiikan tuolloin vielä vallalla olleita, lähinnä perinnetuotteiden erityisesti kalevalamittaisen runouden - ikään ja alkuperään liittyneitä tutkimusintressejä. Historiallisiin aineistoihin perustuvan ja käytännöllisesti katsoen jo hävinneeseen perinteeseen kohdistuvan tutkimuksen kohdalla haasteet ja epävarmuustekijät kieltämättä ovatkin toisenlaiset kuin vaikkapa jonkun nykykirjailijan tuotantoon keskittyvällä tutkijalla.

Kuusen edustaman tekstikriittisen tutkimustradition jälkeisessä folkloristiikassa on kuitenkin edetty suuntiin, joiden myötä käsitykset folkloren tehtävistä ja merkityksistä, samoin kuin folkloren käyttäjistä, ovat kokonaan muuttuneet tai ainakin syventyneet ja tarkentuneet. Vaikka kirjoittamattoman kirjallisuuden käsitettä näkee nykyään käytettävän harvemmin, on perinneviestinnän esteettinen aspekti monien tutkimussuuntausten keskiössä. Niin kutsutun uuden folkloristiikan myötä 1960-luvulla esiin noussut performanssiteoria ja siihen pohjautuva esityskeskeinen folkloristiikka siirsi huomion arkistoaineistojen sijasta eläviin perinteisiin, esittäjiin ja esitystilanteisiin (esim. Ben-Amos 1997; Finnegan 1992, 91-111). Samoihin aikoihin edistynyt kenttätyöteknologia alkoi mahdollistaa esitysten tarkan ja luotettavan dokumentoinnin äänittämällä ja kuvaamalla. Kertojayksilöihin, heidän repertoaareihinsa ja heidän kertojanlaatuaan selittäviin tekijöihin kohdistuva kiinnostus taas on tuottanut tietoa yksilön ja hänen tuntemansa ja käyttämänsä perinteen välisestä suhteesta, yksilöllisen ja yhteisöllisen dynamiikasta sekä yksilön luovasta asemasta perinneainesten hyödyntäjänä (esim. Kaivola-Bregenhøj 1983; Siikala 1984).

Kirjoittamattoman kirjallisuuden käsite on käyttökelpoinen, kun folklorea tarkastellaan estetiikan ja luovuuden näkökulmasta. On kuitenkin pidettävä mielessä sen perustavanlaatuiset erot suhteessa kirjoitettuun kirjallisuuteen. Jos folklore ymmärretään puhtaasti suullisena välittyväksi, on sillä vain kaksi luonnollista olomuotoa: se säilyy latenttina yksilön muistissa, josta se tarvittaessa otetaan käyttöön ja tuotetaan suullisena esityksenä (Honko 1980, 30). Arkistoihin ja ainesjulkaisuihin päätyneet kirjalliset dokumentit eivät sananmukaisesti ole folklorea, vaan enemmän tai vähemmän luotettavia suullisten esitysten representaatioita. On tosin huomattava, että vaikka kirjallisista muistiinpanoista voi vain rajallisesti tehdä päätelmiä itse kerronnasta, on arkistoaineksestakin rekontekstualisoinnin ja kertojien repertoaarien analyysin avulla mahdollista nostaa esiin yksilöllisiä kertojanääniä, henkilökohtaisine strategioineen ja intentioineen. Ansiokas esimerkki tällaisesta tutkimuksesta on Coppélie Cocqin (2008) pohjoissaamelaista kertomusperinnettä koskeva väitöskirja.

Toinen tärkeä ero koskee perinnetuotteiden asemaa teoksina. Yksi folkloren peruspiirteistä on variaatio: toistuessaan saman yksilön esittämänä tai välittyessään kuulonvaraisesti yksilöltä toiselle tapahtuu runossa, laulussa tai kertomuksessa toisinaan 
hienovaraisia, toisinaan huomattaviakin muutoksia. Kertomusten oppimisen, mieleen painamisen ja uudelleen tuottamisen mekaniikkaa on selitetty esimerkiksi skeemateorialla (esim. Siikala 1984, 19-32; Kaivola-Bregenhøj 1988, 25-38) ja mentaalisen tekstin käsitteellä (Honko 1998, 91-99). Kertomus on mahdollista tunnistaa "samaksi”, vaikka se voidaan eri tilanteissa esittää eripituisena, sisältöä, juonta ja kerronnallisia keinoja muunnellen ja vaihtelevalla asenteella. Mitään "normaalitekstiä" ei ole olemassa, vaan esitys mukautuu tilannekontekstiin ja kertojan kulloisiinkin tavoitteisiin.

Kolmas olennainen ero liittyy tekijyyteen. Kun kaunokirjallinen teos on aina kirjoittajansa henkilökohtainen hengentuote, on suullisena välittyvä perinneaines samanaikaisesti sekä yksilöllistä että yhteisöllisesti jaettua. Traditionaalisia, kansainvälisesti tunnettuja teemoja ja motiiveja on mahdollista sopeuttaa täyttämään hyvinkin henkilökohtaisia ilmaisutarpeita. Toisaalta myös omakohtaisiin kokemuksiin perustuvat kertomukset istutetaan yhteisöllisen kerrontatradition muotteihin: vaikka kertomuksen sisältö ei olisi perinteinen, sen kertomisen tapa on. Henkilökohtaisilla kokemuskertomuksillakin on taipumus mukautua paikallisen kerrontatradition konventioihin, mikä toistuvien esitysten myötä usein merkitsee idiosynkraattisten elementtien karsiutumista ja kertomuksen kiteytymistä kollektiivisten odotusten mukaiseksi (Enges 2012, 83-84, 191-201). On myös tunnettua, että eri yksilöt ovat eri tavoin kiinnostuneita suullisen perinteen aineksista ja valikoivat niitä henkilökohtaiseen repertoaariinsa oman persoonallisuutensa, elämänkokemustensa ja perinteen kulloisenkin käyttöarvon mukaisesti. Anna-Leena Siikala on nimittänyt perinneorientaatioksi yksilön perustavanlaatuista asennoitumista perinneaiheita kohtaan. Perinneorientaationsa mukaisesti yksilöt omaksuvat tai hylkäävät kohtaamaansa perinneainesta ja käyttävät ja muokkaavat omaksumaansa omia tarpeitaan vastaavasti. (Siikala 1984, 123-150, 225-227; Enges 2012, 100-102, 252-259.) Tekijyyden ja omistajuuden kysymykset eivät liitykään ensisijaisesti perinnetuotteen alkuperäiseen sepittäjään (vaikka sekin on mahdollista), vaan perinnelajin hallintaan ja kertojan asemaan yhteisössä.

\section{Kotoperäiset saamelaisen kertomusperinteen lajit ja perinteen dynamiikka}

Tenojokilaakso on tunnettu rikkaasta kertomusperinteestään ja hyvistä kertojistaan (esim. Lehtola 1997, 96). Kun Saamelaisen folkloren tutkimusprojekti käynnistyi Turun yliopistossa 1960-luvun puolivälissä, olivat Ylä-Tenon rantakylät luonteva valinta projektin pääkohteiksi. Talvadas (Dálvadas) ja sen naapurikylät osoittautuivat suullisen perinteen aarreaitoiksi. Alue oli historiallisesti kiinnostava ja siellä kohtasivat toisensa kaksi saamelaiskulttuuria, jokisaamelainen ja porosaamelainen. Tavoitteeksi otettiin Talvadaksen kylän koko aikuisväestön toistuva haastattelu ja kyläläisten tunteman suullisen perinteen kaikenkattava dokumentointi. Projekti on tuottanut tiettävästi 
laajimman olemassa olevan saamelaisen folkloren äänitekokoelman - kaikki haastattelut taltioitiin kokonaisuudessaan ja parhaita kertojia haastateltiin useiden vuosien aikana kymmeniä kertoja. (Tarkemmin ks. Huuskonen 2004, 57-83; Enges 2012, 35-56.) Rikkaan haastatteluaineiston pohjalta Marjut Huuskonen (2004) on analysoinut väitöskirjassaan Tenonlaakson kotoperäisiä kertomusperinteen lajeja ja niiden muodostamaa järjestelmää.

Tutkijoiden käyttämät nominaaliset perinnelajitermit vastaavat varsin huonosti tenolaisten itsensä tunnistamia kertomuslajeja. Varsinaisesti tenolainen kertomusperinne jakautuu vain kahteen lajiin. Termi muitalus ja verbi muitalit viittaavat sekä kertomiseen yleensä että tiedon välittämiseen koetusta. Osuvimpia suomenkielisiä käännöksiä muitalukselle ovat '(tosi)kertomus' ja 'muistelus'. Muitalus on laji, jolla raportoidaan totena, todella tapahtuneena pidettyä. Kerrottu voi koskea sekä arkitodellisuutta että laajennettua todellisuutta, esimerkiksi todellisina pidettyjä kohtaamisia yliluonnollisten olentojen kanssa. (Huuskonen 2004, 127-129, 191-196; Huuskonen 2011, 283-284.) Suullisen muitalus-diskurssin vaikutus saamelaisen muisteluskirjallisuuden esikuvana ja perustana on ilmeinen (Lehtola 1997, 96; Hirvonen 1999, 92-93).

Máinnas-lajitermi ja máinnastit-verbi puolestaan korostavat ajallista ja kokemuksellista etäisyyttä kerrottuun. Vaikka kertomus sijoittuisikin tiettyyn aikaan ja paikkaan ja kertoisi kertojan itsensä tai jonkun muun tunnetun henkilön kokemuksista, ei kerronnan välttämättä oleteta olevan realistista. Termillä viitataankin tietynlaiseen kerronnan tapaan, jonka tyylikeinoihin kuuluvat esim. liioittelu ja toistot. Suomenkielisistä termeistä parhaiten vastaavia ovat 'satu', 'tarina' ja 'juttu'. Máinnas on kertomuslaji, jonka puitteissa lahjakas kertoja voi osoittaa kertojantaitojaan ja käyttää erilaisia kerronnallisia ja tyylillisiä keinoja vapaammin kuin muitalus-kertomuksissa. (Huuskonen 2004, 129-142; Huuskonen 2011, 284.) Mielikuvituksellisuuden merkitys on máinnas-kertomuksissa suurempi kuin muitaluksissa, mutta lajeja ei voi pitää yksiselitteisesti toistensa vastakohtina fiktio - tosi -akselilla (Hirvonen 1999, 92).

Näiden lisäksi tenolaisessa perinteessä on käytetty lajitermiä cuvccas, joka ei edellisten tavoin liity kerronnan tapaan, vaan ennen kaikkea kertomuksen totuusarvoon. Sitä käyttämällä otetaan etäisyyttä asioihin, joita ei pidetä mahdollisina tai järkeenkäyvinä. Cuvccas-termi leimaa kertomuksen perättömäksi huhuksi, loruksi, taikauskoksi tai valheeksi. (Huuskonen 2004, 130-133; Huuskonen 2011, 284.)

Kotoperäinen kertomusperinteen järjestelmä ei ole staattinen, vaan lajitermien käyttö vaihtelee yksilö- ja tilannekohtaisesti. Termit ovat kuitenkin tärkeä viestinnällinen väline, kun yhteisön jäsenet arvioivat kuulemiensa kertomusten todenperäisyyttä, tärkeyttä ja esteettisiä arvoja. (Huuskonen 2004, 132-142.) Kertojien ja kuulijoiden kertomuksille antamat merkitykset eivät myöskään välttämättä osu yksiin. Vakavalla mielellä kerrottu muitalus voidaan tulkita mielikuvituksen tuotteeksi, pilke silmä- 
kulmassa kerrottu máinnas taas voidaan toisinaan ottaa täysin todesta. Kertomusten esittämisellä on monia erilaisia tehtäviä ja merkityksiä, joista toiset ovat pysyviä, toiset taas tilannekohtaisesti vaihtelevia. Kertomuksella voidaan pyrkiä vakuuttamaan kuulijat kerrotun todenperäisyydestä, mutta yhtä hyvin johtaa heitä harhaan ja testata heidän herkkäuskoisuuttaan. Kertomusten avulla viihdytetään, osoitetaan omia kertojantaitoja, opetetaan, varoitetaan, kontrolloidaan kuulijoiden käyttäytymistä, pelotellaan, parodioidaan, pilaillaan ja ilmaistaan ryhmäidentiteettiä. On ilmeistä, että kertomuksilla ja kerronnan tavoilla on yhteisöissä moninainen - joskaan ei rajaton - märä erilaisia funktioita. Kaiken kaikkiaan kerronta on aina intentionaalista toimintaa, joka täyttää sekä kertojan ilmauksellisia että erilaisia yhteisöllisiä tarpeita. (Cocq 2008, 22, 150-166, 230-234; Enges 2012, 114-116.)

\section{Kertoja luovana yksilönä}

Tenonsaamelaisessa kulttuurissa tunnettua, yhteisön arvostamaa miespuolista kertojayksilöä on kutsuttu 'tarinakuninkaaksi' (máinnasgonagas) tai 'tarinahäräksi' (máinnasheargi). Naispuolisesta kertojasta taas on voitu käyttää nimitystä 'kentänpäänakka' (gieddegeašahku, gieddegeašgálgu); nimitys on monimerkityksinen ja tarkoittaa mytologista naisolentoa, maan alla asuvaa viisasta tietäjämuoria, mutta yhtä hyvin todellista, kertojantaidoistaan tunnettua naista. (Huuskonen 2004, 160-165.) Arvonimen ansainnut kertoja "näyttelee, matkii, pelleilee, kuvailee ja kertoo kertomuksia, satuja ja tosiasioita. Kertomukset ovat usein pitkiä ja polveilevia, ja kertoja pistää niissä koko kertojantaitonsa esille" (Huuskonen 2004, 161).

Hyvinä tunnetut kertojat ovat hallinneet suullisen perinteen eri osa-alueita eri tavoin. Arvostettuja ovat olleet yhtä hyvin tarkan historiallisen tiedon välittäjät kuin eloisat tarinankertojatkin. Máinnastit-kerrontaa voidaan lajille tyypillisten piirteiden, kuten fiktiivisten elementtien, liioittelun ja näennäisesti vakavan kerronnan perusteella tarkastella ekspressiivisenä valehteluna (Bauman 1986, 11-32), viihteellisenä "tyhjän puhumisena”, jonka oikeasta luonteesta perinneyhteisön jäsenet tavallisesti ovat tietoisia. Hutera tasapaino uskottavuuden ja epäuskottavuuden välillä rakentuu usein kertojayksilön hyvälle perinteen tuntemukselle ja taidolle yhdistellä luovasti perinteisiä ja omasta mielikuvituksesta kumpuavia elementtejä.

Esimerkkejä idiosynkraattisten ja perinteisten ainesten yhteen sulauttamisesta löytyy Saamelaisen folkloren tutkimusprojektin aineistosta runsaasti. Tarinakuninkaan maineessa ollut Ola Samuel Rasmus kehitteli näkemästään unesta hyvin strukturoituneen, yliluonnollisia aiheita sisältävän elämyskertomuksen, jota hän alkoi kertoa ikään kuin todella tapahtuneena. Kertomuksesta tuli osa hänen aktiivirepertoaariaan ja samalla hänen yksityisomaisuuttaan; kertomus oli paikallisesti tunnettu, mutta sitä ei kerrottu eteenpäin. (Enges 2012, 228-244.) Hänen poikansa, niin ikään hyvänä 
kertojana tunnettu Olavi, puolestaan hyödynsi perinteistä uskomusmotiivistoa luodessaan "omakohtaisen kokemuskertomuksen" gufihtar-maahisesta, joka tulee sisälle taloon ja käyttelee vesipumppua yön pimeydessä. Tutkijoille hän paljasti kertovansa sitä huvikseen herkkäuskoisille ihmisille - kertomus on tulkittavissa parodiaksi oikeasta muitaluskertomuksesta. (Enges 2012, 219-223.) Samalla tavoin Olavi Rasmuksen Ilmariveli kertomuksessaan eahpáraš-lapsivainajaolennon kohtaamisesta ja surmaamisesta noudattelee pääosin uskomuksellista kollektiivitraditiota, mutta maustaa kertomustaan myös tradition vastaisilla aineksilla. Jotkut kuulijoista ovat ymmärtäneet kertomuksen todellisen luonteen ja suhtautuneet siihen huvittuneesti, joillekin se on ollut pelottava todiste rauhattomien vainajaolentojen olemassaolosta. (Enges 2012, 224-228.)

\section{Kuka omistaa kertomuksen?}

Kirjoittaessaan vuonna 2002 perinneaineistojen tekijänoikeuksista Lauri Honko esitti tärkeän talvadaslaista kerrontakulttuuria koskevan havainnon: kun Ola Samuel Rasmus kuoli vuonna 1972, siirtyivät jotkut hänen keskeisrepertoaariinsa kuuluneista kertomuksista perheen vanhimman pojan Olavin repertoaariin. Yhteisössä näyttää vallinneen ääneen lausumaton säännöstö ja yhteisymmärrys siitä, kenen kertomuksia muiden on soveliasta esittää. Tätä Honko kutsui luonnolliseksi tekijänoikeudeksi, joka rajaa kertomukset tiettyjen yksilöiden omaisuudeksi ja joka ainakin joissakin tapauksissa näyttää siirtyvän perintönä sukupolvelta toiselle. (Honko 2002.)

Kysymys tekijyydestä on kirjoittamattoman kirjallisuuden kohdalla esitettävä toisin kuin kirjoitetun kirjallisuuden. Koska folkloren kertoja on väistämättä sen kerrontakulttuurin edustaja, johon on itse sosiaalistunut, eivät hänen kertomuksensa voi olla täysin yksilöllisiä teoksia, vaikka idiosynkraattisen aineksen osuus olisi niissä suurikin. Toisaalta kertoja on auktori siinä mielessä, että hän tuottaa kertomuksen jokaisella esityskerralla uudestaan, omien kertojantaitojensa sallimissa rajoissa. Erityisesti arvostettu, hyvän kertojan maineessa oleva yksilö voi saada aseman auktorina, omien kertomuksensa sepittäjänä, mikä fiktiivisten kertomusten osalta usein tarkoittaa poikkeuksellista kykyä etääntyä kollektiivitraditiosta ja soveltaa perinneaineksia luovasti. Realististen kertomusten kohdalla taas kertojalla on todistajan rooli: kun kertomus kerrotaan omakohtaisena, omaan kokemukseen perustuvana, on kertojalla omistusoikeus kertomuksen lisäksi myös alkuperäiseen kokemukseen. Kuulijoiden kannalta kertomuksen tekee kiinnostavaksi jaettu kulttuurinen ymmärrys kokemuksesta. (Vrt. Shuman 2005, 29, 149-162.) Kuten edellä esitetyt esimerkit osoittavat, kokemus voi olla yhtä hyvin kuviteltu kuin todellinenkin.

Tekijyys voidaan ymmärtää myös väljemmin, oikeutena kertomuksen esittämiseen (Shuman 2005, 9, 35). Jotkut kertojat tulevat tunnetuiksi tiettyjen lajien, kuten kaskujen tai satujen taitajina ja näiden itseoikeutettuina esittäjinä. Talvadaslaisista kertojista 
Ilmari Rasmus tunnettiin yhteisössä juuri satuperinteen ylläpitäjänä. Hän oli omaksunut repertoaarinsa pääasiassa enoltaan Aslak Guttormilta, joka oli seudulla oman sukupolvensa ainoa varsinainen sadunkertoja ja jonka eloisaa kerrontaa Ilmari kuunteli innokkaasti lapsuudestaan asti. (Enges 2012, 257.)

Saamelaisen folkloren tutkimusprojektin aineiston valossa näyttää siltä, että paikallinen kertomusperinne jakautuu yhtäältä yhteisöllisesti jaettuun, vapaasti käytettävissä olevaan kollektiivitraditioon, ja toisaalta sen pohjalta nouseviin erityisiin, kertojayksilöiden "omistamiin" kertomuksiin. Kollektiivitraditio voidaan määritellä perinneteemojen, motiivien ja kertomusten varastoksi, josta kaikki yhteisön jäsenet ovat ainakin jollakin tavalla tietoisia ja josta he voivat ammentaa oman kertojanlaatunsa mukaisesti, jos lainkaan. (Enges 2012, 74-75.) Omistettujen kertomusten esitysoikeus taas perustuu luonnolliseen tekijänoikeuteen, josta yhteisöllä on omat kirjoittamattomat sääntönsä. Näkemykseni onkin, että saamelaiseen kertomusperinteeseen ja kerrontakulttuuriin liittyy tekijyyden ja omistajuuden aspekteja, jotka monessa suhteessa rinnastuvat saamelaisen joikukulttuurin säännöstöihin (esim. Jouste 2006, erit. 276, 280). Saamelaisen folkloren tutkimusprojektin aineistoon perustuvissa tutkimuksissa tästä on jo saatu vakuuttavaa näyttöä, mutta lajissaan ainutlaatuinen ääniteaineisto voisi tarjota mahdollisuuden aiheen perusteellisempaankin selvittelyyn.

Saamelaisen kirjoittamattoman kirjallisuuden tekijyyttä ja tekijänoikeuksia koskevat kysymykset ovat kuitenkin laajakantoisempia kuin yksittäisiä, Talvadaksen kaltaisia perinneyhteisöjä koskevia. Tällä hetkellä ajankohtaiset kysymykset aineettomasta kulttuuriperinnöstä ja siihen liittyvistä sopimuksista ja lainsäädännöstä nostavat keskustelun toiselle tasolle. Kun kyseessä on alkuperäiskansan oikeus omaan kulttuuriperintöönsä (ks. esim. Lehtola 2004; Näkkäläjärvi 2010), on kyettävä määrittelemään, mikä on pohjoiskalottialueen muiden väestöryhmien folkloresta erottuvaa, erityisesti saamelaista folklorea. Joikuperinteen kohdalla tilanne lienee suhteellisen selvä, sillä vastaavanlaisia laulukulttuureja ei pohjoisimpia vienankarjalaisalueita lukuun ottamatta Fennoskandiasta löydy. Kertomusperinne on usein kansainvälisesti levinneiden aihepiiriensä vuoksi ongelmallisempi. Monet aihepiirit ja kertomustyypit - esimerkiksi uskomusperinteen maahisia ja vainajaolentoja koskevat - esiintyvät sisällöllisesti vastaavanlaisina myös alueen valtaväestöjen folkloressa. Vanhempi ja ilmeisen virheellinen on käsitys, että saamelaiset olisivat olleet yksipuolisesti perinneaiheiden vastaanottajia ja konservatiivisia säilyttäjiä. On kuitenkin osoitettu, että lainautumista on tapahtunut vastavuoroisesti sekä eri saamelaisryhmien että alueen muiden väestöryhmien kesken (Huuskonen 2011, 277; Enges 2012, 248-249).

Omaleimaisen saamelaisen kertomusperinteen ja kerrontakulttuurin olemassaoloa ei kuitenkaan ole syytä kyseenalaistaa. Pyrkimys märitellä kertomuksia alkuperältään suomalaisiksi, ruotsalaisiksi, norjalaisiksi tai saamelaisiksi ei ole kovin hedelmällinen 
lähtökohta; hyödyllisempää on tarkastella tapoja, joilla kertojayksilöt ovat omaksuneet ja hyödyntäneet monikielisellä ja -kulttuurisella alueella risteileviä vaikutteita (Cocq 2008, 230). Folkloristisen saamentutkimuksen tulevia haasteita onkin tähänastista syvällisemmin selvittää, mikä tekee yksittäisestä kertomuksesta tai jonkin yhteisön kertomusperinteen kokonaisuudesta luonteenomaisesti saamelaisen. Ilmeisesti erityisyyttä tulee sisältöjen sijasta etsiä kerrontatilanteiden ja -konventioiden erityispiirteistä, kertomusten sidonnaisuudesta kieleen ja identiteettiin sekä kertomusperinteen sopeutumisesta saamelaiseen elämäntapaan ja luonnonympäristöön.

Tutkimuksen piirissä on ja kauan sitten luovuttu käsityksestä folkloresta "kollektiivisen luomistyön” tuloksena ja ymmärretty yksilön merkitys perinteen tuottamisessa ja välittämisessä. Perinneyhteisöjen jäsenet taas tavallisesti tunnistavat luonnollisen tekijänoikeuden ja siihen liittyvät korrektiusvaatimukset. Kuten Saamelaiskäräjien puheenjohtaja Klemetti Näkkäläjärvi (2010) aineettoman saamelaisen kulttuuriperinnön suojelua koskevassa puheessaan toteaa, henkisen perinteen asemaa on tarkasteltava samanaikaisesti sekä saamelaiskulttuurin kollektiivisena omaisuutena että yksittäisten taiteilijoiden taideteoksina. Paikalliset tarinahärät ja kentänpäänakat ovat olleet - ja ovat yhä - luovia, joskin perinnesidonnaisia ja perinteestä ohjautuvia sanataiteilijoita omissa yhteisöissään. Suulliselle perinteelle tyypillisestä yhteisöllisen ja yksilöllisen rinnakkaisuudesta johtuen saamelaisen kirjoittamattoman kirjallisuuden tekijyys ja omistajuus sijoittuvat samanaikaisesti niin etniselle, alueelliselle, paikalliselle kuin henkilökohtaisellekin tasolle.

\section{Lähteet}

Bauman, Richard 1986. Story, Performance, and Event. Contextual Studies in Oral Narrative. Cambridge: Cambridge University Press.

Ben-Amos, Dan 1997. Performance. Thomas A. Green (ed.), Folklore. An Encyclopedia of Beliefs, Customs, Tales, Music, and Art. Vol. II. Santa Barbara: ABC-CLIO, 630635.

Cocq, Coppélie 2008. Revoicing Sámi Narratives. North Sámi Storytelling at the Turn of the 20th Century. Sámi Studies 5. Umeå: Umeå University.

Enges, Pasi 2012. "Minä melkein uskon." Yliluonnollinen ja sen kohtaaminen tenonsaamelaisessa kulttuurissa. Turun yliopiston julkaisuja. Turku: Turun yliopisto.

Finnegan, Ruth 1992. Oral Traditions and the Verbal Arts. A Guide to Research Practices. London \& New York: Routledge.

Hirvonen, Vuokko 1995. Sydämeni palava. Johdatus saamelaiseen joiku- ja kertomusperinteeseen, taiteeseen ja kirjallisuuteen. Oulun yliopiston taideaineiden ja antropologian laitoksen julkaisuja A. Kirjallisuus 5. Oulu: Oulun yliopisto.

Hirvonen, Vuokko 1999. Saamenmaan ääniä. Saamelaisen naisen tie kirjailijaksi. Helsinki: SKS. 
Honko, Lauri 1980. Kertomusperinteen tutkimustavat ja niiden tulevaisuus. Pekka Laaksonen (toim.), Kertojat ja kuulijat. Kalevalaseuran vuosikirja 60. Helsinki: SKS, $18-38$.

Honko, Lauri 1998. Textualising the Siri Epic. Folklore Fellows' Communications No. 264. Helsinki: Suomalainen Tiedeakatemia.

Honko, Lauri 2002. Perinneaineistojen tekijänoikeuksista ja käyttösäännöistä. Elore 2/2002. http://www.elore.fi/arkisto/2_02/hon202.html (4.4.2015).

Huuskonen, Marjut 2004. Stuorra-Jovnnan ladut. Tenonsaamelaisten ympäristökertomusten maailmat. Helsinki: SKS.

Huuskonen, Marjut 2011. Näkökulmia saamelaiseen folkloreen. Irja Seurujärvi-Kari, Petri Halinen \& Risto Pulkkinen (toim.), Saamentutkimus tänään. Helsinki: SKS, 271-297.

Jouste, Marko 2006. Suomen saamelaisten musiikkiperinteet. Anneli Asplund, Petri Hoppu, Heikki Laitinen, Timo Leisiö, Hannu Saha \& Simo Westerholm (toim.), Suomen musiikin historia. Kansanmusiikki. Helsinki: Werner Söderström Osakeyhtiö, 272-307.

Kaivola-Bregenhøj, Annikki 1983. Folkloren kertoja. Auli Viikari (toim.), Kirjallisuudentutkijain Seuran vuosikirja 35. Helsinki: SKS, 55-70.

Kaivola-Bregenhøj, Annikki 1988. Kertomus ja kerronta. Helsinki: SKS.

Kuusi, Matti 1963. Kirjoittamattomasta kirjallisuudesta. Matti Kuusi (toim.), Suomen kirjallisuus I. Kirjoittamaton kirjallisuus. Helsinki: SKS \& Kustannusosakeyhtiö Otava, 7-30.

Lehtipuro, Outi 1980. Perinteentutkimus tienhaarassa. Outi Lehtipuro (toim.), Perinteentutkimuksen perusteita. Porvoo \& Helsinki \& Juva: Werner Söderström Osakeyhtiö, 7-18.

Lehtola, Veli-Pekka 1997. Saamelaiset - historia, yhteiskunta, taide. Inari: KustannusPuntsi.

Lehtola, Veli-Pekka 2004: Oikeus omaan historiaan. Saamelainen kulttuuriperintö ja historiankirjoitus. Tuomas Magga \& Veli-Pekka Lehtola (toim.), Sámiid rievttit gillii ja historjái. Saamelaisten oikeudet kieleen ja historiaan. Oulu: Giellagas-instituutti, 52-65.

Näkkäläjärvi, Klemetti 2010. Klemetti Näkkäläjärven puhe saamelaisen aineettoman kulttuuriperinnön suojelusta Suomessa. Sámediggi / Saamelaiskäräjät. http://www. samediggi.fi/index.php?option=com_docman $\&$ task=doc_download $\&$ gid $=1417$ (7.7.2015). 
Seurujärvi-Kari, Irja 2011. Kirjallisuus ja taiteet - sulautumisen uhasta kohti sisäistä elämää. Irja Seurujärvi-Kari, Petri Halinen \& Risto Pulkkinen (toim.), Saamentutkimus tänään. Helsinki: SKS, 298-326.

Shuman, Amy 2005. Other People's Stories. Entitlement Claims and the Critique of Empathy. Urbana \& Chicago: University of Illinois Press.

Siikala, Anna-Leena 1984. Tarina ja tulkinta. Tutkimus kansankertojista. Helsinki: SKS. 